\title{
IMPROVING THE MANUFACTURING PROCESS OF ALUMINIUM RIMS
}

doi: 10.2478/czoto-2021-0004

Date of submission of the article to the Editor: 27/11/2020

Date of acceptance of the article by the Editor: 15/03/2021

\author{
Czerwińska Karolina ${ }^{1}$ - orcid id: 0000-0003-2150-0963 \\ Pacana Andrzej ${ }^{1}$ - orcid id: 0000-0003-1121-6352 \\ ${ }^{1}$ Rzeszów University of Technology
}

\begin{abstract}
The aim of the study was to indicate the reasons for non-compliance of aluminium rim castings and, using quality management instruments (Pareto-Lorenzo diagram and $5 \mathrm{WHy}$ method?), elimination or reduction of non-compliant products. The object of the research was an aluminium rim, while the diagnostic process of the object of the research was based on the quality control of the chemical composition of the casting, the control of mechanical properties and the control of the continuity of the material structure by radiographic and microscopic methods. On the basis of the research carried out, it was found that a sensitive casting area is the front edge of the rim rim - a significant number of porosity clusters were identified in this area. The reason for their occurrence was also specified - too rapid flooding of moulds, which resulted in gassing of the alloy. The identified cause had its origins in human resources mismanagement, namely the lack of training of the newly recruited employee. So far, the company has not carried out analyses of quality problems with the use of a sequential quality management methodology, so the implemented corrective actions have not always led to the full achievement of quality objectives. The presented sequential method, which is a combination of diagnostic and control tests and quality management instruments, is a universal way to monitor the level of quality of products and to quickly correct nonconformities.
\end{abstract}

Keywords: management engineering, quality engineering, quality control

\section{INTRODUCTION}

Currently, manufacturing companies are building their position and competitive advantage on the basis of optimized production processes. However, the search for savings in financial outlay and time should not adversely affect the quality of the products themselves. Production in foundry technology is burdened with many difficulties. The issue of proper production of aluminium castings is extremely important due to wide possibilities of using the foundry for production of various structural parts (Czerwińska et al., 2019; Pacana et al., 2018). The use of foundry technologies enables the production of complex construction details which are components of vehicles, machines, devices or measuring equipment. Taking into account the progressive 
development in terms of construction complexity and the associated increase in the requirements for the components used, it is necessary to conduct material and technical tests (Czekaj et al., 2012, Łuszczak and Dańko, 2013). In the context of ensuring the desired quality of details, the key issue is the control of the process itself and the correctness of the production of castings (Ostasz et al., 2020; Zheng et al., 2012).

Comprehensive methods are constantly being sought to detect incompatibilities, but also to prevent them by detecting the sources of their origin or even looking for causes that cause problems within these sources. The methods enabling the implementation of the indicated activities are quality management methods, which, when skilfully applied, allow to increase the quality level of the offered products (Langabeer, 2108; Łybacki and Zawadzka, 2008; Pawlowski and Pawlowski, 2018). Many authors of literature studies related to the control of aluminium castings present the use of single quality management instruments such as: FMEA (Gawdzinska et al., 2017; Piatkowski and Kaminski, 2017), value stream mapping (Dadashnejad and Valmohammadi, 2019) or Ishikawa diagram (Chokkalingam et al. 2017; Suarez-Barraza and RodriguezGonzalez, 2019) to analyse the causes of non-compliance. However, at present, more and more attention is being paid to the use of several complementary quality management instruments, thus indicating their universality and comprehensive approach to production problems (Bris, 2016; Chang, 2020; Dale et al., 1998; Skotnicka-Zasadzien et al., 2017). In this respect, the Pareto-Lorenzo diagram is correlated with the $A B C$ method, which is used to identify the most important group of factors generating a given problem (Pacana et al., 2018). However, there is still a lack of a configured quality control method that would allow for an in-depth causal analysis of production non-conformities.

\section{ANALYSIS}

\section{Aim, scope and subject matter}

The aim of the tests is to perform diagnostics of rim casting in terms of correctness of chemical composition, mechanical properties measured in the area of external and internal rim flange, spokes and acquisitions and diagnostics in terms of continuity of material structure by radiographic method. An additional objective is to identify, by means of quality management tools, the sources of the most serious non-conformity of rim castings used in passenger cars and to analyse and eliminate them.

Due to the increase in the number of non-compliant wheel castings $(2.5 \%$ compared to the previous quarter), the subject of the study was an aluminium wheel casting for BMW passenger cars. Figure 1 shows the subject of the study together with the names of the characteristic rim areas. The survey concerned batches of products made in the 4th quarter of 2019 in one of the foundry enterprises located in the southern part of Poland. The company produces aluminium wheels.

\section{Testing procedure}

The diagnostic process of the subject of the study was based on the control of the quality of the chemical composition of the casting, mechanical properties and the control of the continuity of the material structure by radiographic and microscopic methods. The analysis of the detected irregularities was carried out using quality management tools (Pareto-Lorenz diagram, 5WHY method). The correlation between the diagnostic methods and tools used to analyse the causes of non-compliance is shown in Figure 2. 


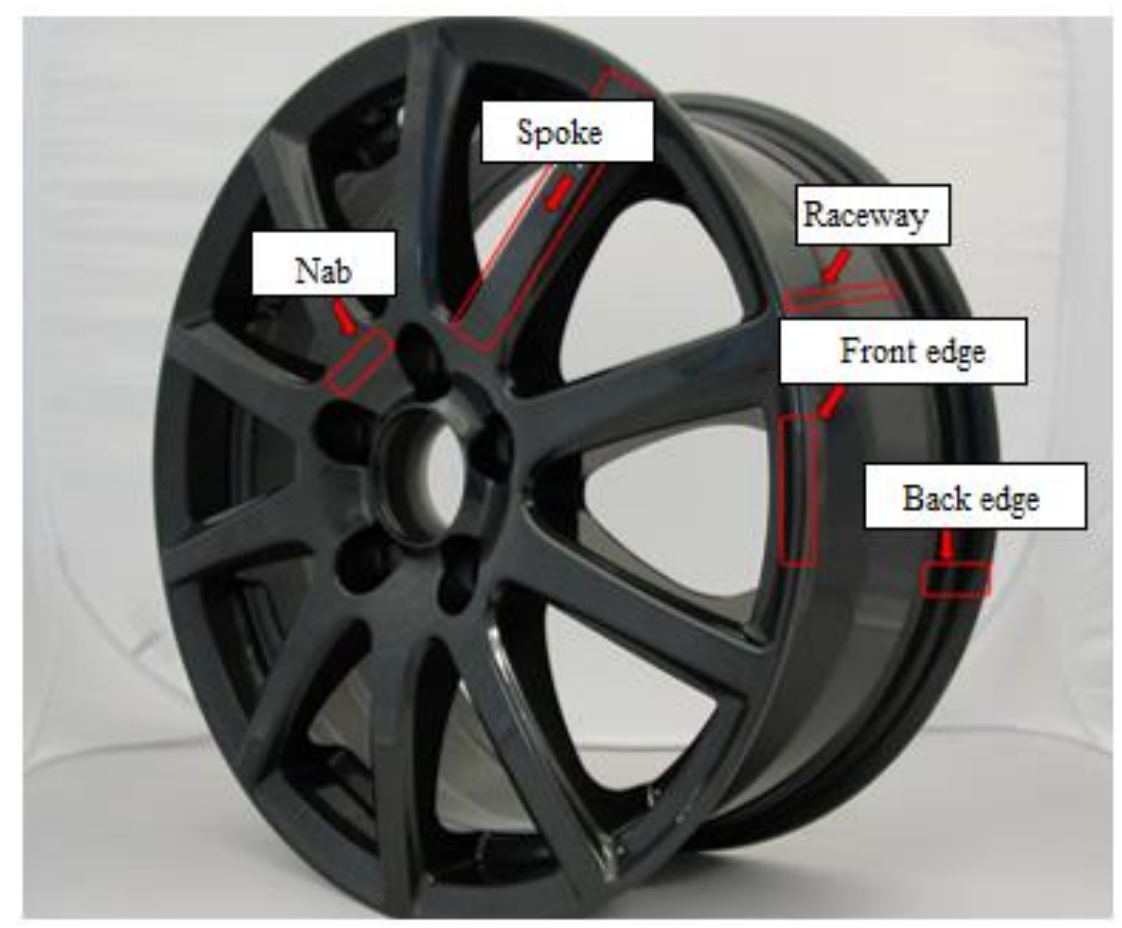

Fig. 1. Subject of tests with names of particular product areas

The control of the chemical composition of the rim casting was performed by means of a JY 10000 RF glow discharge optical emission spectrometer. The test specimens were in the form of a cylinder with a diameter of $25 \mathrm{~mm}$ and a thickness of $20 \mathrm{~mm}$.

The test of mechanical properties was carried out on samples with a diameter and measuring length of $15 \mathrm{~mm}$ at a distance of 20,30 and $40 \mathrm{~mm}$ from the base of the cylinder. The tests were carried out using a RKM 250/50 (Roel \& Kothaus) type testing device equipped with an electronic extensometer.

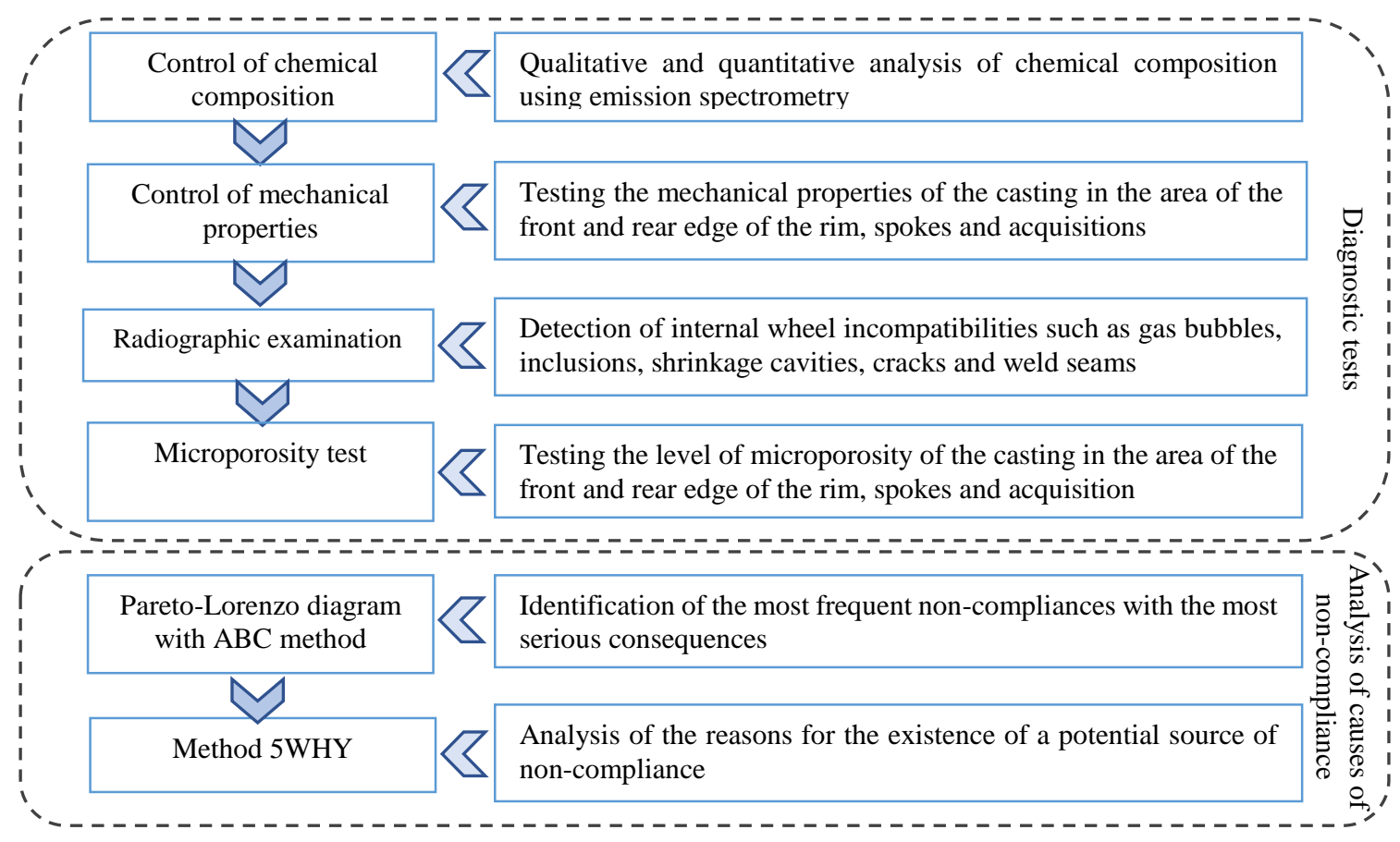

Fig. 2. Sequence of methods used in the study 
The radiographic research uses the Bosello High Technology Industrial X-Ray. The control is performed in semi-automatic mode. The average length of the $\mathrm{X}$-ray test cycle is one minute.

Samples for metallographic testing were cut from characteristic casting areas on the Struers Labtom-3 metallographic cutter. The microstructure was observed on the Zeiss Neophot 2 metallographic microscope.

The analysis of the causes of non-compliance was carried out using the Pareto-Lorenzo diagram correlated with $\mathrm{ABC}$ and $5 \mathrm{WHY}$ methods. The Pareto-Lorenz diagram with the $A B C$ method was made in order to specify the most significant nonconformities in terms of their number and severity of effects. The 5WHY method has been applied to the most relevant cause of non-compliance identified in order to identify its source.

\section{RESULTS}

The obtained results of chemical composition control (determination of trace elements content) of a cast rim made of high quality aluminium alloy AISiMg 7 are presented in Table 1.

Table 1

Chemical composition (determination of trace element content)

\begin{tabular}{|l|l|l|l|l|l|l|l|}
\hline & Si [\%] & Fe [\%] & Cu [\%] & Mn [\%] & Mg [\%] & Zn [\%] & Ti [\%] \\
\hline Min & 6.5 & - & - & - & 0.20 & - & 0.05 \\
\hline Max & 7.5 & 0.20 & 0.05 & 0.05 & 0.35 & 0.10 & 0.15 \\
\hline The result & 7.1 & 0.1194 & 0.001 & 0.0016 & 0.2582 & 0.0070 & 0.116 \\
\hline
\end{tabular}

According to the data in Table 1 concerning tests of alloy casting additives, it can be seen that they meet the customer's expectations and are in line with the standards set out in the following table.

The next test carried out was to diagnose mechanical properties. In the strategic areas of the rim, i. e. in the front and rear areas of the rim flange and in the spoke area and 5 measurements of mechanical properties were taken and then the mean values were extracted from them. The results of the mechanical properties test are presented in Table 2.

Table 2

Measurements of mechanical properties of individual rim casting areas

\begin{tabular}{|l|l|l|l|l|l|l|l|}
\hline \multicolumn{6}{|l|}{ Front edge of the rim } \\
\hline Requirements & 1 & 2 & 3 & 4 & 5 & $\mathbf{x}^{-}$ \\
\hline $\begin{array}{l}\mathrm{Rp} 0,2 \\
{[\mathrm{Mpa}]}\end{array}$ & $\geq 190$ & 190.4 & 190.1 & 187.3 & 188.9 & 188.6 & 189.1 \\
\hline $\mathrm{Rm}[\mathrm{Mpa}]$ & $\geq 240$ & 242.1 & 240.2 & 243.1 & 238.6 & 239.7 & 240.7 \\
\hline As [\%] & $\geq 4.5$ & 4.6 & 4.6 & 4.7 & 4.3 & 4.4 & 4.5 \\
\hline Back edge of the rim \\
\hline $\begin{array}{l}\text { Rpo,2 } \\
{[\mathrm{Mpa}]}\end{array}$ & $\geq 190$ & 202.6 & 206.4 & 206.9 & 203.9 & 204.0 & 204.8 \\
\hline Rm [Mpa] & $\geq 240$ & 282.6 & 286.3 & 274.9 & 283.9 & 289.6 & 283.5 \\
\hline As [\%] & $\geq 4.5$ & 15.0 & 13.4 & 10.7 & 10.8 & 12.5 & 12.5 \\
\hline
\end{tabular}




\begin{tabular}{|c|c|c|c|c|c|c|c|}
\hline \multicolumn{8}{|l|}{ Spoke } \\
\hline $\begin{array}{l}\mathrm{Rp}_{0,2} \\
\text { [Mpa] }\end{array}$ & $\geq 170$ & 182.7 & 178.8 & 182.7 & 184.2 & 179.8 & 181.6 \\
\hline $\mathrm{Rm}$ [Mpa] & $\geq 210$ & 242.0 & 230.7 & 230.5 & 243.8 & 240.3 & 237.5 \\
\hline As [\%] & $\geq 2$ & 4.3 & 3.3 & 2.5 & 4.4 & 4.6 & 3.8 \\
\hline \multicolumn{8}{|l|}{ Naba } \\
\hline $\begin{array}{l}\mathrm{Rp}_{0,2} \\
{[\mathrm{Mpa}]}\end{array}$ & $\geq 160$ & 194.2 & 192.6 & 191.9 & 191.9 & 190.2 & 192.1 \\
\hline $\mathrm{Rm}$ [Mpa] & $\geq 205$ & 253.8 & 238.4 & 247.3 & 250.3 & 246.1 & 247.2 \\
\hline As [\%] & $\geq 2$ & 4.8 & 2.7 & 4.1 & 4.7 & 3.8 & 4.0 \\
\hline
\end{tabular}

According to the measurements of the rim's mechanical properties in the specified casting areas in Table 2, it can be seen that the values obtained in the area of the rear edge of the rim's flange, spokes and purchases are within the prescribed standards. The exceptions are the parameters of mechanical properties from the area of the front edge of the rim flange, which is a sensitive casting area in the tested batch of products. The results of the radiographic examination of the area of the front edge of the rim rim flange are shown in Figure 3. The obtained results indicate the occurrence of dispersed porosity in the medium loaded zone.

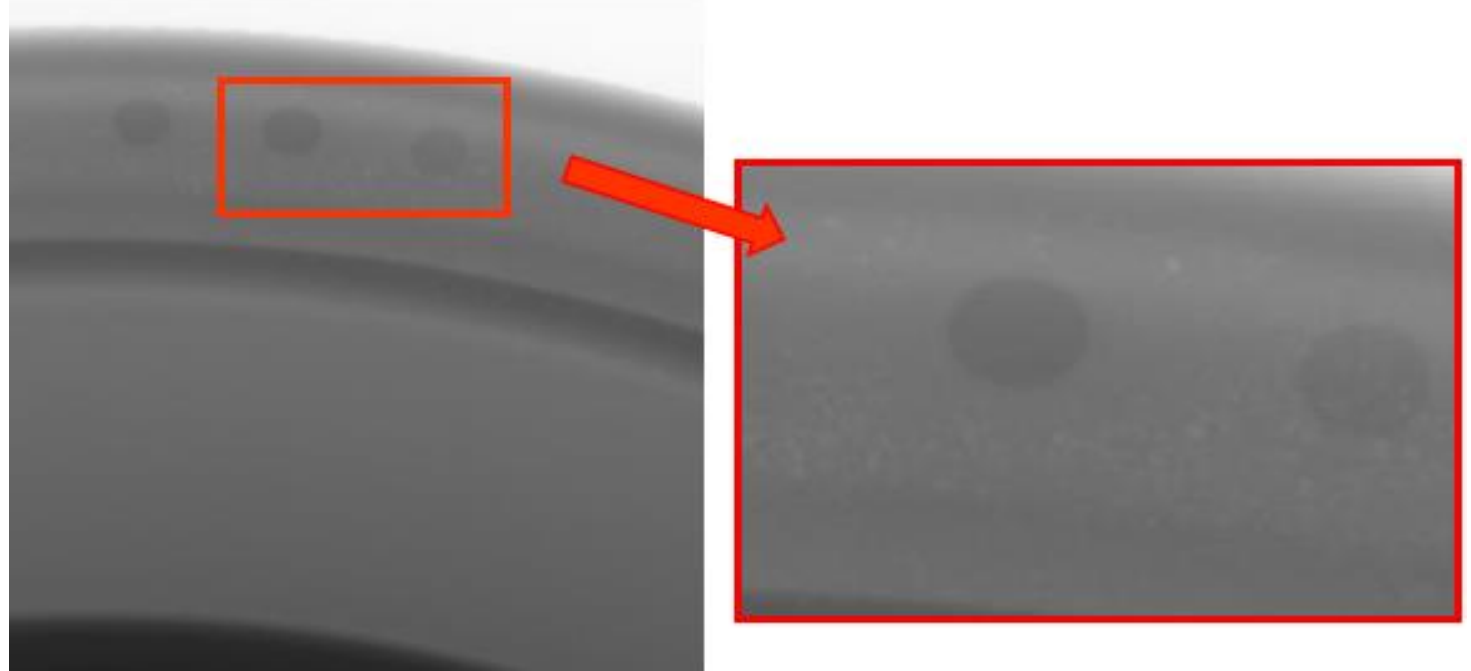

Fig. 3. X-ray result - area of front edge of rim flange

In order to accurately characterize the size of the noncompliance, microporosity tests are carried out from the characteristic rim casting areas, which allow observation of the material structure. The results of the study are indicated in Table 4.

Table 3

Measurements of mechanical properties of individual rim casting areas

\begin{tabular}{|l|l|l|l|l|}
\hline Area & Front edge of the rim & $\begin{array}{l}\text { Back edge of the } \\
\text { rim }\end{array}$ & Spoke & Naba \\
\hline $\begin{array}{l}\text { Maximum admissible } \\
\text { microporosity [\%] }\end{array}$ & 1 & 1 & 2 & 2 \\
\hline The result [\%] & 3.8 & 0.04 & 0.02 & 0.08 \\
\hline Maximum expansion & $1[\mathrm{~mm}]$ & \multicolumn{3}{|l}{} \\
\hline
\end{tabular}


On the basis of the results of the microporosity test of the casting (Table 3), it can be concluded that only the area of the front edge of the rim rim rim does not fall within the defined standards. The value of the maximum expansion in this area was $3.8 \%$ exceeding the permitted percentage threshold by $2.8 \%$.

\section{Analysis}

At present, in the production company, each of the manufactured parts is subjected to various inspections carried out after successive stages of the production process. In order to completely eliminate or reduce the number of non-compliant products, an analysis of the causes of defects occurring in the area of the front edge of the rim was undertaken. To identify the causes of non-compliance, it was decided to use a combination of quality management tools.

The first step in the analysis of the front edge area of the rims used for passenger cars was the Pareto-Lorenz analysis, which was carried out to identify the most significant discrepancies in terms of their number (Figure 4). The types of non-compliance were marked successively: N1 - porosity, N2 - systolic cavity; N3 - exfoly; N4 - undercasting N5 - interjecting of foreign material; N6 - scorching; N7 - fastening; N8 mechanical damage; N9 - incompatibility of felling thickness; N10 - cold casting cracks; N11 - government; N12 - hot casting cracks.

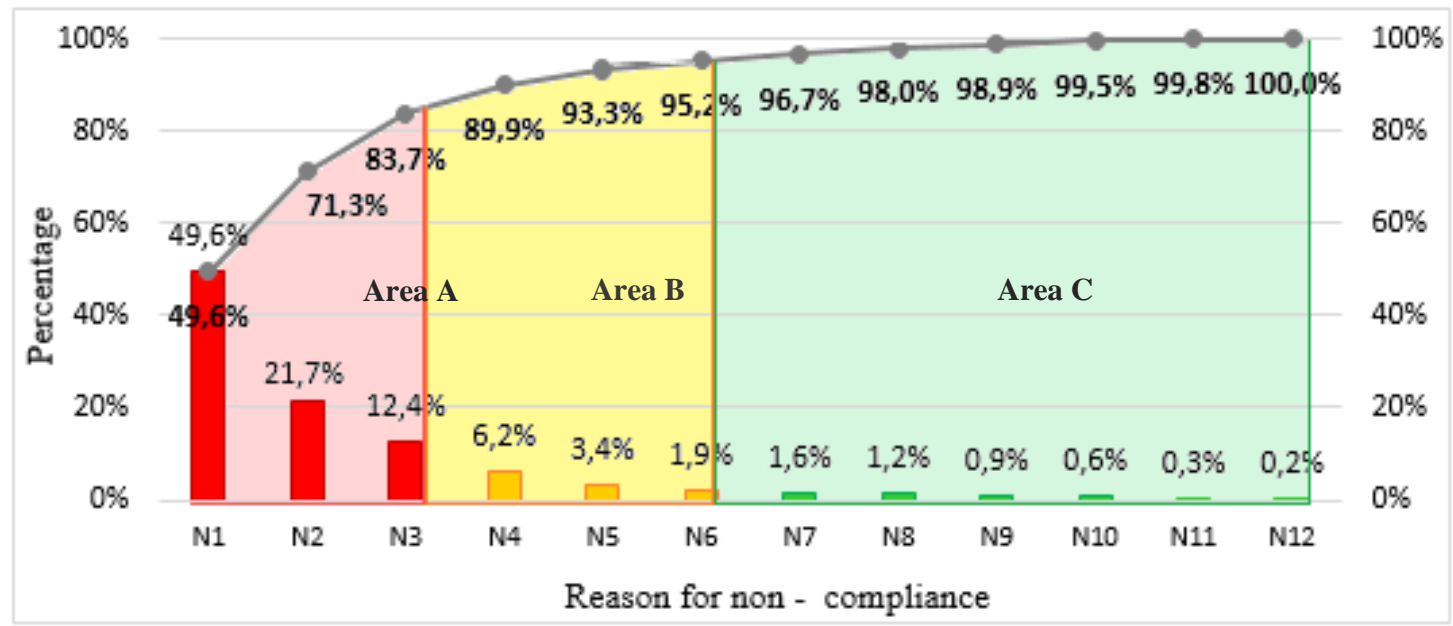

Fig. 4. Pareto Lorenzo diagram with $A B C$ method for the front edge area of the rim

The Pareto-Lorenzo graph shows that 3 types of casting defects (the presence of porosity, shrinkage and peeling) are responsible for $83.7 \%$ of discrepancies identified during the quality control of the rim production process. In the first step, eliminate the cause that causes the highest number of nonconformities - porosity - as it reaches 49 . $6 \%$ of all identified nonconformities. In the subsequent stages of improvement activities, the occurrence of nonconformities which are also in area A, i. e. systolic cavities and delusions, should be excluded.

As part of further statistical analysis, the porosity values located in the area of the front edge of the rim of the castings under investigation were considered. A histogram showing the distribution of defects as a function of incidence and its accumulation was developed (Figure 5). 


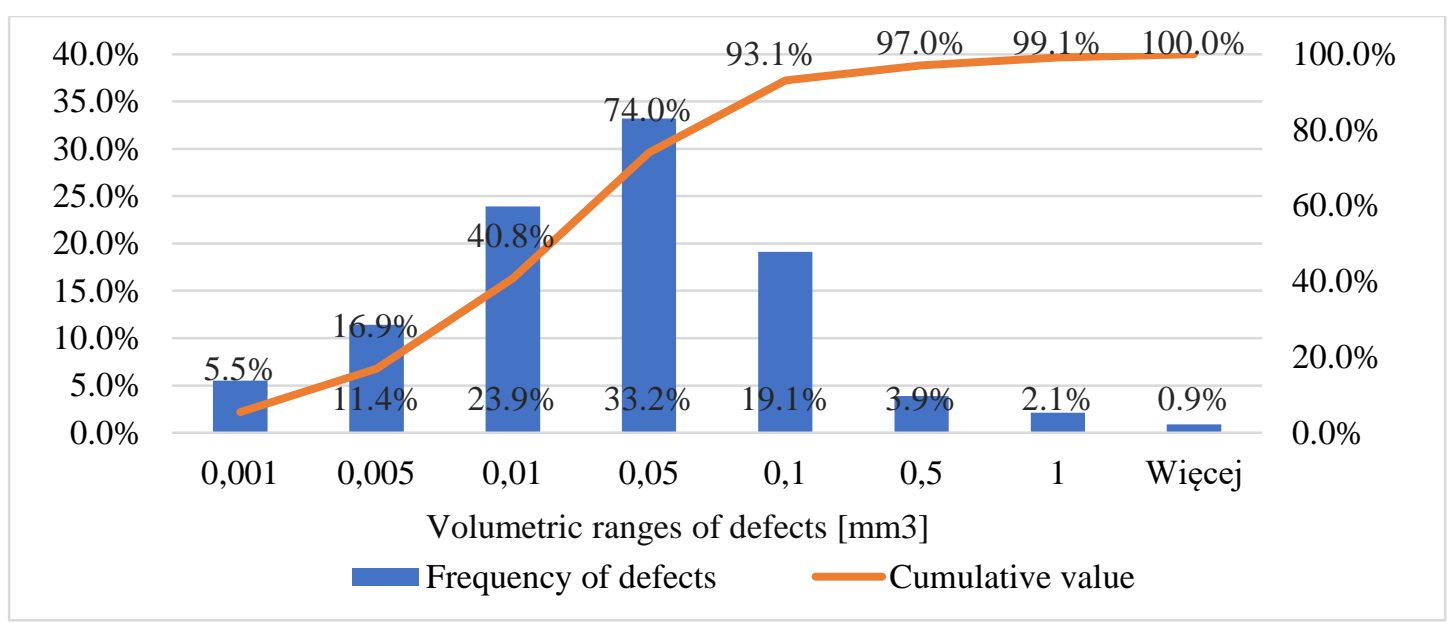

Fig. 5. Histogram showing the frequency of the specified defect groups

The largest number of internal inconsistencies identified during the casting of parts is about $0.05 \mathrm{~mm} 3$ and, combined with defects from 0.001 to $0.05 \mathrm{~mm} 3$, it accounts for $74 \%$ of all analysed discontinuities (Figure 5).

Due to the large number of porosities not within the tolerance limits, action has been taken to identify the causes of the problem. For this purpose the 5WHY method was used (Figure 6).

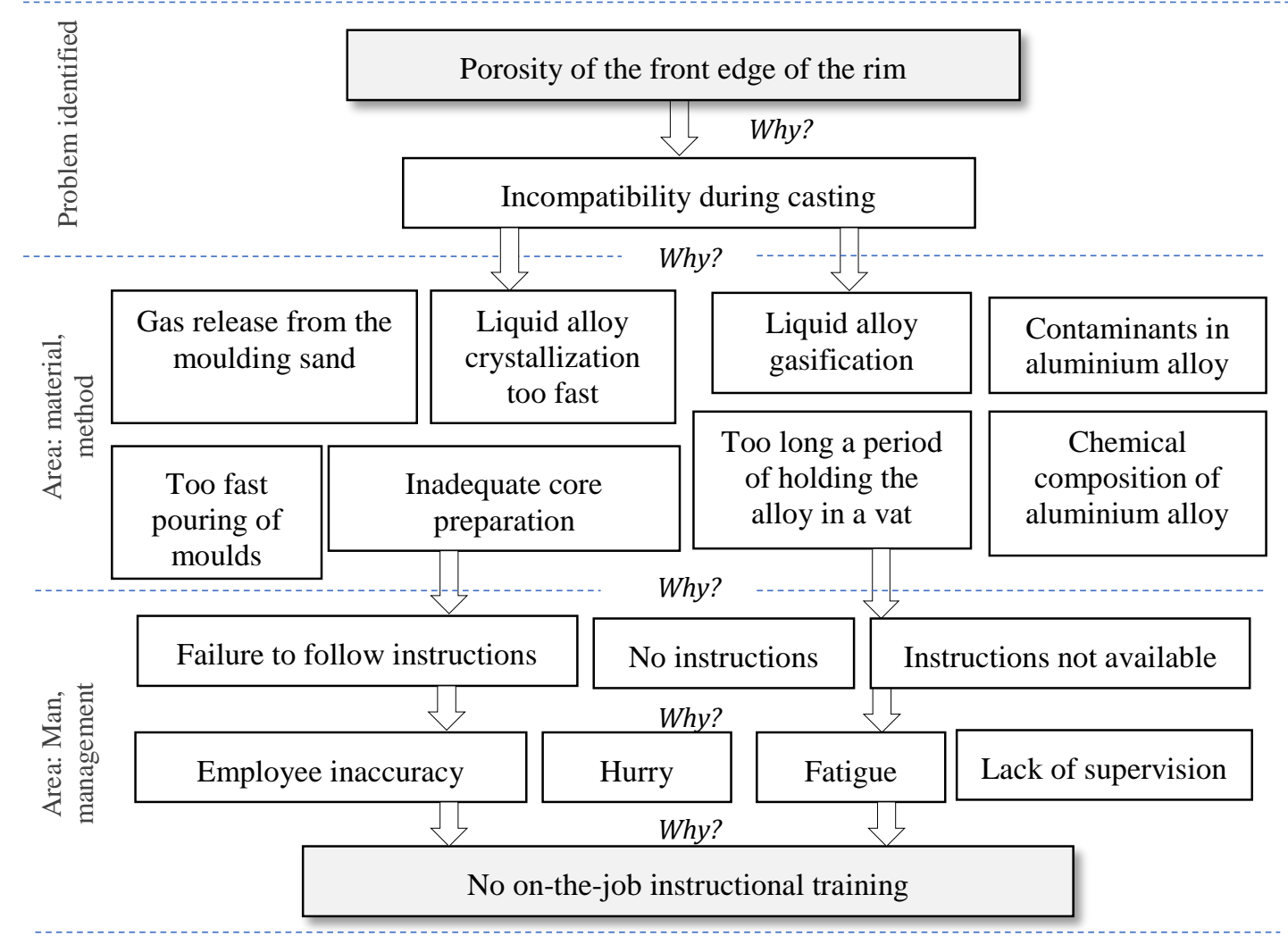

Fig. 6 . Method 5 Why for the problem of the presence of porosity clusters in the area of the front edge of the rim rim

On the basis of the analysis carried out (Figure 6), it was found that the source cause of cracks in compressor body castings was a lack of proper evaporator qualification due 
to a lack of instructional training at the workplace. The identified cause has been included in the human/management area.

\section{DISCUSSION}

Constant monitoring of the processes carried out in the company and quality control are the key to the success of any organization wishing to maintain a competitive position on the market. The concept of a detailed analysis of the causes of non-compliance presented in the study, including the identification of areas where the defects are most frequently located and the indication of the type of these defects, as well as the indication of their causes in conjunction with the application of configured integration of quality management tools is a useful and universal way to increase the quality level of the offered products. The methodology presented contributes to the elimination of the identified noncompliances and the implementation of effective preventive actions.

The front of the rim edge turned out to be the sensitive area of the aluminium rim in the tested batch. In this area, porosity was the most common irregularity, the cause of which was identified as too rapid flooding of the moulds, which resulted in gassing of the alloy. The identified cause had its origins in mismanagement of human resources, namely the lack of training of the newly recruited employee.

Further research will be related to the implication of the proposed sequence of analysis of casting's nonconformity, which is an effective way of solving quality problems in the production of other products offered by the company.

\section{Reference}

Bris, R., 2016. Cost oriented statistical decision problem in acceptance sampling and quality control, Applied Mathematics In Engineering And Reliability, 19-26.

Czekaj, E., Karwiński, A., Pączek, Z., Pysz, S., 2012. Nowy sposób wytwarzania odlewów precyzyjnych ze stopu miedzi w formach ceramicznych, Archives of Foundry Engineering, Komisja Odlewnictwa Polskiej Akademii Nauk Oddział w Katowicach, 12(2), 9-16.

Czerwińska, K., Dwornicka, R., Pacana, A., 2019. Analysis of non-compliance for the cast of the industrial robot basis, 28th International Conference on Metallurgy and Materials, Brno, TANGER LTD., ISBN: 978-80-87294-92-5.

Dadashnejad, Aa., Valmohammadi, C., 2019. Investigating the effect of value stream mapping on overall equipment effectiveness: a case study, Total Quality Management \& Business Excellence, 30(3-4), 466-482.

Dale, B., Boaden, R., Wilcox, M., Mcquater, R., 1998. The use of quality management techniques and tools: an examination of some key issues, International Journal Of Technology Management, 16(4-6), 305-325.

Gawdzinska, K., Chybkowski, L., Przetakiewicz, W., Laskowski, R., 2017. Application of fmea in the quality estimation of metal matrix composite castings produced by squeeze infiltration, Archives of Metallurgy and Materials, 62(4), 2171-2182.

Chang, As., Control points and measures of a quality process, International Journal Of Materials \& Product Technology, 20(1-3), 205-209.

Chokkalingam, B., Raja, V., Anburaj, J., Immanual, R., Dhineshkumar, M., 2017. Investigation of shrinkage defect in castings by quantitative ishikawa diagram, Archives of Foundry Engineering, 17, 174-178. 
Langabeer, Jr., 2018. Performance management methods and tools, Performance Improvement In Hospitals And Health Systems: Managing Analytics And Quality In Healthcare, 2nd Edition, 43-61.

Łuszczak, M., Dańko, R., 2013. Stan zagadnienia w zakresie odlewania dużych odlewów strukturalnych ze stopów aluminium, Archives of Foundry Engineering,13(3), $113-116$.

Łybacki, W., Zawadzka, K., 2008. Wspomaganie diagnostyki wad odlewniczych narzędziami zarzadzania jakością, Archiwum Technologii Maszyn i Automatyzacji, Poznań, 28(1).

Ostasz, G., Czerwińska, K., Pacana, A., 2020. Quality management of aluminum pistons with the use of quality control points, Management Systems In Production Engineering, 28(1), 29-33.

Pacana, A., Czerwińska, K., Bednarowa, L., 2018. Comprehensive improvement of the surface quality of the diesel engine piston, Metalirgija, 58(3-4), 329-332.

Pacana, A., Czerwińska, K., Bednarowa, L., 2018. Discrepancies analysis of casts of diesel engine piston, Metalurgija, 57(4), 324-326.

Pawlowski, K., Pawlowski, E., 2018. Complementarity of modern management methods and tools, and its impact on economic and organizational performance of enterprises, Empirical Results from Polish Enterprises, Advances In Ergonomics Of Manufacturing: Managing The Enterprise Of The Future, 606, 213-221.

Piatkowski, J., Kaminski, P., 2017. Risk assessment of defect occurrences in engine piston castings by FMEA method, Archives Of Foundry Engineering, 2017, 17(3), 107-110.

Skotnicka-Zasadzień, B., Wolniak, R., Zasadzień, M., 2017. Use of quality engineering tools and methods for the analysis of production processes - case study, Proceedings Of The Second International Conference On Economic And Business Management, 33, 240-245.

Suarez-Barraza, Fm, Rodriguez-Gonzalez, Fg., 2019. Cornerstone root causes through the analysis of the Ishikawa diagram, is it possible to find them? A first research approach, International Journal Of Quality And Service Sciences, 11(2), 302-316.

Zheng, Y., Li, Am., Liu, Jj., Wang, Sh., 2012. Modeling of Quality Control Points of Equipment Maintenance Process, International Conference On Quality, Reliability, Risk, Maintenance, And Safety Engineering, 1432-1434. 